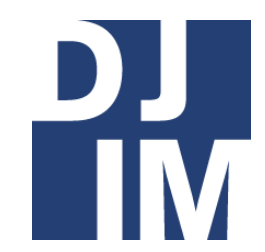

Volume 13

Spring

2017

djim.management.dal.ca |

\title{
Newfoundland and Labrador: Rolling Blackouts, the Liberty Reports, and the Role of Reliability in Energy Provision
}

Sydni Kind

Rowe School of Business, Dalhousie University

\begin{abstract}
Newfoundland's electrical system experienced significant outage periods in J anuary 2013 and 2014 that left a large portion of the Island population without power for days at a time. This launched an investigation by the Board of Commissioners of Public Utilities (the "Board") into the supply issues and power outages. These events raise the question of what the systemic reasons for the blackouts were and what role the Board should play in regulating a monopolized public utilities industry. This paper contends that the lack of a "reliability" requirement in the legislated service standard for public utilities in Newfoundland and Labrador constrained the Board's ability to effectively regulate the province's energy system and played a fundamental role in the blackouts experienced. Newfoundland and Labrador must take steps to actively and effectively regulate an energy system that is isolated from the mainland bulk power grid to ensure citizens have access to electricity despite adverse weather events. To do this, the legislation must incorporate reliability requirements and the Board must actively monitor whether these requirements are met. This paper does not address further reports produced or legislative and regulatory responses to the issue after December 2015. Further research, particularly into the effectiveness of the Muskrat Falls connection and the implementation of the Liberty Consulting Group recommendations, would help to evaluate the system's reliability going forward.
\end{abstract}

\section{Introduction}

The Newfoundland and Labrador electrical system underwent significant outage periods in J anuary 2013 and 2014 that left a large portion of the Island population without power for days at a time. The inability of the electric system to maintain operations, even considering record winter weather occurrences, raised concerns with consumers and the government about the 
system's ability to survive long-term. It was understood that the Muskrat Falls connection, at the time anticipated in 2016 or 2017, was expected to relieve much of that stress. Regardless, the Board of Commissioners of Public Utilities (the "Board") launched an investigation into the supply issues and power outages experienced by the Island Interconnected System. The intent was to determine the system's adequacy and reliability going forward in two contexts: prior to and after the connection with Muskrat Falls. The Board employed the Liberty Consulting Group ("Liberty") to conduct an analysis of the system and identify weak points that required improvement. The purpose of the investigation was to ensure that outage periods experienced in 2013 and 2014 would be mitigated to the greatest extent possible in future years. At the date of writing, Liberty had published an interim report and $P$ hase I final report, detailing the implications for the system prior to its connection with Muskrat Falls. While the Board and the public utilities responded to the interim report, there has been no official response to the Phase I report published in December 2014 (The Liberty Consulting Group ("Liberty”), 2014A).

This paper analyzes whether systematic reasons were at the root of the significant outage periods and what role the Board should play in regulating the monopolized energy sector in Newfoundland and Labrador. This discussion will start with an analysis of the energy sector in Newfoundland and Labrador, drawing on the fact that it is a monopoly system, which is in part owned and operated by the Crown. The analysis will then turn to the electricity outages and the events that transpired, resulting in widespread outages over extended periods of time throughout the
Island. The paper then examines the Board's authority to commence an investigation into these public utilities issues, rooted in statutory authority, and the Liberty Reports' responses to these issues. Further, the paper examines the lack of reliability requirements for the Newfoundland and Labrador energy sector, considering prevailing North American standards, particularly with respect to the impact of the North America Electric Reliability Corporation ("NERC") on the North American regulatory landscape.

This paper argues that the failure of the legislative scheme to demand sufficient service standards of the public utilities, in failing to incorporate a "reliability" requirement, constrained the Board's ability to effectively regulate the Newfoundland and Labrador energy sector. It is recommended that Newfoundland and Labrador incorporate a reliability component into its public utility standards to provide the Board with leverage in order to ensure that customers have access to sufficiently reliable public utilities despite adverse weather events.

\section{The Newfoundland Energy Sector}

Public utilities are defined "as businesses so 'affected with the public interest' that they must be regulated by government regarding entry into (and exit from) the market, rate charges to customers, rate of return allowed to owners, and for the requirement to serve all customers within their area of operation" (Halsbury's Laws of Canada, 2014, para. 6). The responsibility of public utilities largely falls in the provincial government sphere, per section 92A of the Constitution Act, 1867, with some power allocated to federal and municipal governments (Halsbury's Laws of Canada, 2014, para. 17). In Newfoundland, public utilities are identified as: 
[A] person, firm or corporation that owns, operates, manages or controls in this province equipment or facilities for...the production, generation, storage, transmission, delivery, or providing of electric power or energy, water or heat either directly or indirectly to or for the public or a corporation for compensation. (Public Utilities Act, 1990, s. 2(1)(e))

In understanding the energy sector, one must understand and consider the role of corporations. The regulatory power of a board is focused on "fixing just and reasonable rates and in protecting the integrity and dependability of the supply system" (Halsbury's Laws of Canada, 2014, para 10), with restrictions on power most clearly seen in the board's ability to dictate whether a sale is allowed, but not how the gains are allocated (ATCO Gas and Pipelines Ltd. v Alberta (Energy and Utilities Board), 2006).

Two entities largely control the Newfoundland and Labrador energy sector: Newfoundland Power and Newfoundland and Labrador Hydro ("Hydro"). Hydro is largely responsible for generating electricity and Newfoundland Power is responsible for distribution to a substantial portion of the province's consumers. Essentially, while Hydro is often the point of incident for loss of power, Newfoundland Power has the capacity to interrupt service to customers, and, as such, is required to commence rolling blackouts and outages as needed in the event of insufficient supply. This dynamic often results in consumer anger directed at Newfoundland Power; however, these actions are the direct responsibility and consequence of Hydro's operations (Liberty, 2014A).

Newfoundland and Labrador: Rolling Blackouts

\subsection{Newfoundland Power}

In operation since 1885, Newfoundland Power runs "an integrated generation, transmission and distribution system throughout the island portion of Newfoundland and Labrador...[and focuses on providing] safe, reliable electricity in the most cost-efficient manner possible" (Newfoundland Power, 2015A). Fortis Inc. owns all common shares of Newfoundland Power Inc., making it the largest investorowned utility nationally. Newfoundland Power purchases a significant portion of its electricity (90-93\%) from Hydro, supplementing it with its own smaller hydroelectric stations on the Island. The Board regulates its operations. The company is responsible for supplying electricity service to more than 256,000 customers, which represents almost 90 percent of the province's electricity customers, excluding select areas throughout the province that are the responsibility of Newfoundland and Labrador Hydro exclusively: Great Northern Peninsula, smaller coastline communities, and Labrador (Newfoundland Power, 2015A).

In its 2015 third-quarter financial statements, the company addressed the service disruptions issue, indicating that because of the investigation to date, the Liberty Report on the outages indicated Newfoundland Power was largely operating in compliance with industry best practices (Newfoundland Power, 2015B). This account accords with the Liberty Report findings, as Hydro played a more significant role in the outages and their long-term effects than Newfoundland Power (Liberty, 2014A).

\subsection{Newfoundland and Labrador Hydro}


Hydro is an energy producer, and is a whollyowned subsidiary of the crown corporation Nalcor Energy, established in 2007 by provincial legislation. As of its 2014 Annual Report, Nalcor Energy operates fifteen entities, eleven of which are wholly-owned subsidiaries (Nalcor Energy, 2014). Hydro's mandate involves ensuring a "...safe, reliable and least-cost electricity supply is available to meet current demand and future growth" (Nalcor Energy, 2013). It aggregates its customers into three broad groups: Newfoundland Power, more than 38,000 rural residential and commercial customers, and major industrial customers. As of 2012, these divisions represented $82.4 \%, 14.8 \%$, and $3.5 \%$ of Hydro's regulated revenue respectively (Nalcor Energy, 2013, p. 17). Electricity demand "....is met through a combination of hydroelectric generation, thermal generation and power purchases including wind generation" (Newfoundland Labrador Hydro, n.d.).

The company's 2014 Annual Report discussed Liberty's Phase I report findings, where it recognized that "[d]uring the period January 2 to January 8, 2014, there were instances when Hydro experienced a shortage in the generation supply and therefore, was unable to meet the supply requirements on Hydro's Island Interconnected System" (Nalcor Energy, 2014, p. 20). Additionally, upon reviewing the Liberty report, the company "found many of the recommendations align with Hydro's own findings and work which Hydro has been addressing...[and] Hydro will continue to work closely with the [Board] and Liberty regarding the implementation of actions to provide reliable electricity service to the people of Newfoundland and Labrador" (Nalcor Energy, 2014, p. 20).

\section{Electricity Outages Triggering the B oard Investigation}

Two significant periods of outage in the winters of 2013 and 2014 resulted in the Board investigation of Newfoundland and Labrador's electricity providers. As the Board was conducting investigations concerning these outages, it experienced another outage episode in March 2015. These outages were widespread but primarily concentrated on the Island portion of the system, where there is a lack of connection to mainland power. It caused several consumers to lose power, at times for significant durations. These events drew high levels of consumer concern in terms of the public utilities and the government's ability to effectively manage, oversee, and direct them in the provision of electricity in the province (Liberty, 2014A). The paper will analyze this in terms of the events leading to the outages, as well as the public outcry in the wake of the J anuary 2014 outages that resulted in the Board's investigation of the public utilities.

\subsection{Events Resulting in the Outages Experienced}

Because of heavy and blowing snow on the morning of J anuary 11, 2013 on the Island portion of the province, customers experienced extensive Island-wide outages. Hydro cited equipment failures as the main cause of widespread outages and expansion of the problem to the Island's central and western regions. Additional issues with communication and equipment during restoration efforts led to further failures and outages (Liberty, 2014A, p. 1). A blizzard damaged one of the Holyrood generating plant's three generators, raising concerns about the adequacy of the system to supply electricity during the winter season. At the 
time, Hydro's Vice-P resident of Regulated Operations, J im Haynes, indicated that while there was sufficient generation for the company's forecasted power load, poor weather and/or the breakdown of another generator would compromise the system and result in requesting consumers to employ energy conservation strategies, including reduced use during peak times (Pennell, 2013). The utility defined peak times as "between 6 and 9 a.m. and between 5 and 6 p.m. from December to March", and indicated that rolling blackouts were a worstcase scenario if consumer load reduction was not effective in curbing energy use (Pennell, 2013). The utility's means of reducing grid load is to identify an area whose load equals that of the overage, and then cut electricity to the area for a period, before continuing to a new area and repeating the process (Pennell, 2013). These events were rather minimal, considering the events that occurred the following January, and, as such, the combination of weather and equipment failures were likely viewed as a unique, onetime event that could be rectified by the repair of the Holyrood generator. However, after the events of J anuary 2014, the Board found it necessary to conduct a more thorough and rigorous analysis of the system (Liberty, 2014A; Pennell, 2013).

Two distinct events led to Island customers experiencing outages throughout the period of J anuary 2 to 8, 2014, which saw nearly $75 \%$ of Newfoundland Power retail customers without power, many for extended periods of time. Shortages in Hydro's generating resources resulted in an initial series of rotating outages. These generationrelated outages were a result of several generation facilities being out of service at a time when Hydro anticipated critically high

Newfoundland and Labrador: Rolling Blackouts loads with the ability to threaten the capacity to provide continuous service. In terms of megawatt capacity, there was approximately 255 megawatts of supply out of commission at the time of the blackouts, equating to nearly $13 \%$ of the system's normal operating capacity. Arguably, this insufficiency alone had the capacity to bring down the electric grid in the event of a spike in demand (Liberty, 2014A, pp. 1-2). Secondly, while Hydro and Newfoundland Power worked to recover from these insufficiencies, equipment and operations issues resulted in another round of electricity outages. Consumers experienced both widespread outages and additional rotating outages. The equipment and operations outages compounded the already impaired system, particularly the Sunnyside station transformer fire on J anuary 4, 2014. Nearly $15 \%$ of outages were a result of capacityinduced rotating outages experienced on J anuary 2 and 3, 2014, while 80\% were equipment-related outages that followed. It is noteworthy that only $5 \%$ of the outages were directly attributable to winter storm conditions (Liberty, 2014B). Thus, while much of the media publicity surrounding the events of J anuary 2014 focused on the weather as a direct, significant cause of the outages, this did not prove to be the case. It was primarily based on the inability of the system to generate sufficient electricity to supply the grid.

\subsection{Public Outcry over the Outages Experienced in J anuary 2014}

The rolling blackouts of J anuary 2014 were touted as Newfoundland's most significant story of 2014. Manifesting in the hashtag \#darknl," the public outcry served to "underscore the weaknesses in the provincial power supply" (Gushue, 2014). It also created a movement that allowed citizens to 
constantly call into question the ability of the public utilities to provide consistent power at the slightest power outage experienced. Amid the outages, Newfoundland's Premier Kathy Dunderdale spoke out in support of the electrical system, four days after the rolling blackouts commenced, voicing her "absolute confidence in Nalcor" and "absolute confidence in Newfoundland Power" (The Canadian Press, 2014). This was in the wake of nearly $36 \%$ of Newfoundland's power customers being affected at the peak of the events on J anuary 4, 2014. The Dunderdale government responded to the public outcry by promoting the Muskrat Falls project, which was intended to alleviate much of the load concerns. Nalcor President and CEO, Ed Martin, spoke out in support of Hydro's systems, citing the unusually bad weather as the cause of the widespread failures (The Canadian Press, 2014). He went on to state that Nalcor "plan[s] the system longterm...[with] a very detailed asset management plan in place that recognizes the age of the assets and the quality of the assets" (The Canadian Press, 2014).

These comments were a knee-jerk reaction to the public outcry, which do not conform to the evidence presented in the Liberty Report results. The rolling blackouts and outages of January 2014 are also speculated to have played a significant role in the Premier's decision to resign on January 22, 2014 (Gushue, 2014). Amid calls for a formal inquiry by opposition parties, Dunderdale insisted the Board was fully capable of reviewing the power failure (The Canadian Press, 2014). The question here is whether the Board has sufficient legislative capacity to investigate the reliability of the system in this way.

\section{Newfoundland Board of Commissioners on Public Utilities}

The Board is Newfoundland's "independent, quasi-judicial regulatory body appointed by the Lieutenant Governor in Council" (Board of Commissioners of Public Utilities ("Board"), n.d.). It is responsible for administering nine key pieces of legislation, among which are the Public Utilities Act, Electrical Power Control Act, and the Act to Amend the Electrical Power Control Act. In addition, the Public Utilities Board Regulations, 1996 set out the regulatory environment and the policies and procedures under which the Board operates (Board, n.d.). The Public Utilities Act permits creation of the Board, the make-up of which is the responsibility of the Lieutenant-Governor in Council. Board commissioners are appointed for 10-year terms, and are eligible to hold a second 10-year term (Public Utilities Act, 1990, s. 6). In accordance with objectivity and removal of bias, "commissioner[s] shall not be directly or indirectly employed by or interested in a public utility or interested in a share, stock, bond, mortgage, security or contract of a public utility that is subject to this Act" (Public Utilities Act, 1990, s. 7(1)).

\subsection{Board Authority to Commence Investigation}

The Board commenced an investigation and hearing into supply issues and power outages on the Island Interconnected System (the "Investigation"), as they determined that the Island Interconnected System must be reviewed with respect to adequacy and reliability:

It is appropriate and necessary to
address how Hydro and
Newfoundland Power will ensure
adequacy and reliability on the Island
Interconnected system over the short,
medium and long-term, which will
require analysis of the adequacy and


reliability of the system after the commissioning of the Muskrat Falls generating facility and the Labrador Island Link. (Board, 2014, p. 3)

In addition, the Board mandated "the process established for this matter should ensure a comprehensive review with full opportunity for interested persons to participate and should also ensure that measures necessary to prepare for the 2014-2016 winter season are addressed as soon as possible" (Board, 2014 , p. 3). After commencing the Investigation in February 2014, the Board aimed to publish its final report by the first quarter of 2015, highlighting the importance of an action-oriented plan and strategy (Board, 2014, Schedule B). The Board identified its investigation as comprising two phases: (1) assessing the adequacy and reliability of supply prior to the Island Interconnected System's interconnection with Muskrat Falls; and (2) assessing adequacy and reliability of supply following the interconnection with Muskrat Falls (Board, 2015, p. 3).

\subsection{Authority arising out of the Public Utilities Act and Electrical Power Control Act}

The Board found authority under the Public Utilities Act and Electrical Power Control Act to launch the Investigation (Board, 2014). Under these acts, the Board has the authority to investigate issues as they arise and when demanded by external complaints. However, it is questionable as to the extent to which the Board is allowed, or more so encouraged, to be proactive in its monitoring of public utilities. Arguably, as the Liberty Reports stress, there are several systemic, long-term issues that culminated in the 2013 and 2014 outages and rolling blackouts that were only compounded further by inclement weather.
The outages over the course of J anuary 2 to 8, 2014 were the impetus for launching the investigation. A primary concern of the Board in initiating the investigation was the longterm implications for the system prior to and after its connection with Muskrat Falls (Liberty, 2014A).

\section{2.a Public Utilities Act}

The Public Utilities Act applies to "public utilities that are subject to the legislative authority of the province", and as such applies to Newfoundland Power and Hydro (Public Utilities Act, 1990, s. 3.1; Public Utilities Act, 1990, s4(1)). The Act creates the boundaries in which the Board can operate and regulate services falling under the Act. It grants the Board general supervisory power over public utilities, with capacity to be informed of compliance, or lack thereof, and force public utility compliance with information requests (Public Utilities Act, 1990 , ss. 16, 17, 62). In terms of service levels, the Board has authority under section 37 to determine whether "service reasonably safe and adequate and just and reasonable is being supplied by the public utility" (Public Utilities Act, 1990, s. 37(2)). Further, section 82 provides broad authority to the Board to investigate matters such as the rolling blackouts of J anuary 2014. Thus, based on these provisions, it is evident that the Board has authority to conduct the investigation into the systems that were the cause of the rolling blackouts and outages in Newfoundland and Labrador to ensure that the service is reasonably safe and adequate.

\section{2.b Electrical Power Control Act}

The Act's power policy speaks to power rates; sources and facilities in the production, transmission, and distribution of power; authority in emergency situations; 
determination of essential employees; and the exclusion of nuclear power as a source of future energy supply (Electrical Power Control Act, 1994, s. 3). The Act's sections about retailer corporate governance (sections 23-25) have yet to come into force. Part II of the Act, Planning, Allocation and Re-Allocation of Power and Facilities, is particularly relevant to the outage events in Newfoundland and Labrador. It grants the Board "the authority and the responsibility to ensure that adequate [emphasis added] planning occurs for the future production, transmission and distribution of power in the province" (Electrical Power Control Act, 1994, s. 6). It also stipulates the Board's powers in inquiring about anticipated shortages:

7. (1) Where a producer or a retailer believes [emphasis added] that it may not be able to supply power sufficient to satisfy the current or anticipated power demands of its customers and prospective customers in accordance with the power policy set out in section 3 , it may request the public utilities board to conduct an inquiry into the matter.

(2) The Lieutenant-Governor in Council may request the public utilities board to conduct an inquiry into the matter of the adequacy of supply and the ability of producers and retailers to meet the current or anticipated power demands of consumers...

(3) Where the public utilities board believes [emphasis added] that producers and retailers collectively or individually will not be able to satisfy...the current or anticipated power demands of consumers in the province, the public utilities board may further inquire into the matter. (Electrical P ower Control Act, 1994, s. 7)

The requirement that the power supply be deemed "adequate" by the Board logically underpins the lack of sufficient supply seen during the J anuary 2013 and more so, the J anuary 2014 outages and rolling blackouts. The system is simply not held to a standard that requires sufficient supply when demand is above Newfoundland's anticipated peaks, and there is little, if any, additional supply buffer present to accommodate unforeseen events.

\section{Liberty Report Findings and Recommendations}

The Board retained Liberty "to examine the causes of widespread electricity outages experienced by customers on the Integrated Island System ("IIS") of Newfoundland and Labrador from January 2 through 8, 2014" (Liberty, 2014A). The company has 25 years of experience serving utility regulators, with projects extending to 55 North American jurisdictions, focusing on "ensuring safe, reliable, and cost effective utility service" (Liberty, 2014A, p. ES-1).

The Board contracted Liberty to produce two reports, the first of which recommended actions prior to the Muskrat Falls in-service data. In an interim report dated April 24, 2014, Liberty advanced 46 recommendations to-date for Newfoundland Power and Hydro. At the time, its overall conclusion was that:

The outages of this past J anuary stemmed from two different sets of causes: (a) the insufficiency of generating resources to meet customer demands, and (b) issues with the operation of key transmission system equipment. Liberty found that a continuing 
and unacceptably high risk of outages from such causes remains for the 2015-2017 winter seasons. (Liberty, 2014A, p. ES-1)

Hydro undertook significant work after the release of Liberty's interim report, working to upgrade its systems and complete backlogged maintenance on its infrastructure; however, "[despite] adding nearly 200 megawatts of supply capacity through the new 120 megawatt combustion turbine and securing new capacity arrangements with certain industrial customers, supply remains tight until the interconnection with Muskrat Falls" (Liberty, 2014B, p. ES-2). Liberty also indicated generation reserves were low and Hydro must ensure maintenance completion on its generating units by the agreed December 1 deadline each year (Liberty, 2014B, p. ES-2). The paper addresses several of Liberty's key findings below to provide greater context for the systemic issues at play in Newfoundland and Labrador's energy sector, including the inaccuracy of its load-forecasting formula; failings in its prediction software; insufficient attention to ongoing maintenance; and the inability of the Board to dictate intercompany cooperation. In the Phase I report, Liberty again emphasized the existence of a "continuing and unacceptably high risk of supply-related emergencies until Muskrat Falls comes into service" with the current energy system (Liberty, 2014B, p. 22).

Generation reserves are intended to predict the loss of load probability that a system experiences annually. In general, North America operates on a 'one chance in ten years' loss of load probability, meaning that, with existing reserves, the company's system will only experience a supply-related interruption once in a ten-year span. Contrary to what many would deem industry standard, Newfoundland employs a 'one chance in five years' requirement in its determination of generation reserves required (calculated by Hydro as a loss of load hours ("LOLH") of 2.8). When translated to a percentage basis, it equates to reserves in the $10-12 \%$ range. Liberty questioned the adequacy of this level of reserves, indicating "adequate" should at minimum require margins above the existing range (Liberty, 2014B, p. 19). S pecifically, Liberty stated that if "Hydro modeled a lower LOLH (e.g., a one in ten-year probability) and higher forced outage rates, its resulting estimate of required reserves would move higher" (Liberty, 2014B, p. 19). It further identified that its "experience is that acceptable values for reserve margin also require the use of more intuitive considerations...[which] has particular applicability for small, isolated systems, which lend themselves to practical considerations" (Liberty, 2014B, p. 19). Essentially, Liberty questions the true adequacy of the system, which the Board had deemed adequate for a significant period. The issue that is thus raised is how the Board is working to ensure sufficient standards are put in place and enforced, in order to provide quality public utility services to Newfoundland residents.

Additionally, Liberty found that Hydro's determination of required generation is done through averaging winter conditions, which in effect results in "worst-day winter conditions having a 50/50 chance of being exceeded every year" (Liberty, 2014B, p. 4). This policy fails to place appropriate emphasis on the significant loads colder winter conditions may necessitate and as such, significantly impairs Hydro's ability to provide sufficient and continuous service to customers. The system also permits a greater use of interruptions (i.e. outages and rolling blackouts) than other North American systems Liberty has been 
responsible for analyzing (Liberty, 2014B, p. 4). Liberty found it necessary "to employ a robust, structured examination of how the standards Hydro uses conform to current customer expectations...[particularly as it] has generally been the case that North American utility customer expectations have risen" (Liberty, 2014B, p. 4).

The Liberty Report identified the natural limitations of Newfoundland's prediction software. It is evident from the events of J anuary 2014 that the model is incapable of operating when experiencing conditions not yet learned by the system (i.e. the unusual weather conditions). This requires Hydro to manually adjust models in the event of atypical weather conditions to ensure sufficient supply. Additionally, the model does not calculate the industrial load on the system, and thus these quantities must be manually added to the model's results to ensure sufficient capacity is present. While Hydro is undergoing improvements to the modeling system, it remains unknown to what extent these revisions will serve the company's needs, and the true impact will remain unseen until there is sufficient experience with the new system in place (Liberty, 2014B, p. 15).

Further, Hydro's policy is to ensure that maintenance is complete and all generation capacity is online by December 1 annually, recognizing the likelihood that it will experience winter peak loads in December; however, according to Liberty, Hydro has not achieved that goal (Liberty, 2014A, p. 4). Ensuring that maintenance is complete and generation capacity is operational at the beginning of December should be a priority of the utmost concern for Hydro, and failing this, "[r]eserve planning should not assume such availability to the degree that Hydro remains unable to support it" (Liberty, 2014A, p. 4).

Lastly, as Hydro provides the majority (85\%) of Newfoundland Power's electricity to the grid, there must be a strong foundation of intercompany coordination to rely on in the event of emergencies, such as the rolling blackouts and outages of J anuary 2014. Since Newfoundland Power takes the burden of initiating the blackout and cutting service to its customers, it is essential that there be open communication between it and its provider-Hydro (Liberty, 2014B, p. 105). Referring to the companies' relationship, Liberty indicated that "[t]he nature of their relationship requires a scope and depth of coordination that goes well beyond the needs that even the largest retail customers entail" (Liberty, 2014B, p. 105).

\section{The Newfoundland and Labrador system lacks reliability standards}

While the Board launched an Investigation to "address how Hydro and Newfoundland P ower will ensure adequacy and reliability on the Island Interconnected system" (Board, 2014 , p. 3), the following analysis makes clear that there is no use of the term "reliability" in the Newfoundland and Labrador legislation that the Board can draw from, nor is there a definition of "adequacy." This begs the question of what exactly the Board views as "adequate" and "reliable." In answering this, the paper will review the North American Electric Reliability Corporation ("NERC") standards, as adopted in Alberta and Ontario, in contrast to the existing Newfoundland and Labrador legislated standards.

\subsection{The NERC reliability standards are adopted by much of the industry}


NERC represents "a not-for-profit international regulatory authority whose mission is to assure the reliability of the bulk power system in North America...[with jurisdiction over] users, owners, and operators of the bulk power system, which serves more than 334 million people" (NERC , 2015B). In the United States, NERC has "the legal authority to enforce Reliability Standards with all U.S. users, owners, and operators of the BPS [Bulk Power System] and made compliance with those standards mandatory and enforceable" (NERC, 2014A). NERC is also applicable, either via legislation or memoranda of understanding, in all Canadian provinces excluding Newfoundland and Labrador (NERC, 2014B). This is largely associated with Newfoundland and Labrador's lack of connection to the mainland bulk power grid. The likelihood of compliance with NERC standards, and acceptance of them as part of energy relation in the province, may increase following the Muskrat Falls connection.

\subsection{NERC Stipulates Reliability Standards for its Members}

NERC defines reliability as grounded in the concepts of "adequacy" and "operating reliability." Adequacy is "the ability of the electric system to supply the aggregate electric power and energy requirements of the electricity consumers at all times, taking into account scheduled and reasonably expected unscheduled outages of system components" (North American Electric Reliability Corporation ("NERC"), 2007, p. 5). "Operating reliability" is "the ability of the electric system to withstand sudden disturbances such as electric short circuits or unanticipated loss of system components" (NERC, 2007, p. 5).

Newfoundland and Labrador: Rolling Blackouts
In defining the standard, it is aptly recognized that NERC "cannot require a specific level of adequacy for 'electric facilities or services"' (NERC, 2007). The definition instead incorporates six characteristics into the definition of a system's "adequate level of reliability":

1. The System is controlled to stay within acceptable limits during normal conditions;

2. The System performs acceptably after credible Contingencies;

3. The System limits the impact and scope of instability and cascading outages when they occur;

4. The System's Facilities are protected from unacceptable damage by operating them within Facility Ratings;

5. The System's integrity can be restored promptly if it is lost; and

6. The System has the ability to supply the aggregate electric power and energy requirements of the electricity consumers at all times, taking into account scheduled and reasonably expected unscheduled outages of system components. (NERC, 2007)

There is a disconnect between Newfoundland and Labrador's chosen wording of service requirements and those of NERC. Arguably, defining electricity standards through "adequate planning" and "reasonable service" is at the root of much of the system's reliability issues. NERC bases the entirety of its standards on reliability, the definition of which incorporates adequacy and operational reliability to ensure true system reliability. Newfoundland and Labrador's system fails to do this. 


\subsection{There is no "reliability" requirement for the Newfoundland \& Labrador electrical system}

The legislation in Newfoundland and Labrador lacks a definition of reliability, instead using "reasonable service" (Public Utilities Act, 1990, s. 82) and "adequate planning" (Electrical Power Control Act, 1994, s. 6) to refer to the reliability and future capacity of the province's energy system. Further, the legislation does not define "reasonable service" and "adequate planning," creating further ambiguity about the strength of the provisions. The Public Utilities Act defines "service" as "the use and accommodation given to consumers or patrons, and a product or commodity provided by a public utility, and [equipment used to perform a service)" (Public Utilities Act, 1990, s 2(1)(f)). However, this does not provide a measure of "reasonable," nor is "reasonable" defined in the Interpretation Act to provide additional context (Interpretation Act, 1990). Similarly, neither the Electrical Power Control Act nor the Interpretation Act provide a definition of "adequate planning" (Electrical Power Control Act, 1994; Interpretation Act, 1990). Further, neither provision has been considered by the courts.

The emphasis in the Public Utilities Act is on ensuring "public utility services are reasonably safe, adequate, just, and reasonable" (1990, s. 37). In their present wording, these provisions, which are critical in ensuring citizens have access to electricity, seem incapable of developing an effective electricity system. While a prime concern during the rolling outages was the reliability of the system, the legislation at no point requires the province to have or maintain a "reliable" system (Electrical Power Control Act, 1994; Gushue, 2014; Liberty, 2014A; Public Utilities Act, 1990).
While the legislation itself does not purport to require maintenance of a reliable system, the companies have taken it upon themselves to promise customers "safe, reliable electricity in the most cost-efficient manner possible" (Newfoundland Power, 2015A) and that "a safe, reliable and least-cost electricity supply is available to meet current demand and future growth" (Nalcor Energy, 2013, p. 17). Though these are the mandates of the two primary electricity providers to the Island, there is no legislative mechanism to enforce these reliability standards. Further, and potentially more significant, is an inability to define what reliability means in the supply of electricity in Newfoundland. It is, if anything, an empty promise by the corporations (arguably, specifically Hydro) in an endeavour to garner and maintain consumer confidence in a monopolistic public utility system.

\subsection{Inferring practical definitions of "adequate planning" and "reasonable service"}

Based on a review of courts' interpretations of "adequate," "planning," and "reasonable," and incorporating the Public Utilities Act definition of "service," at minimum the definitions of "adequate planning" and "reasonable service" can be interpreted to impute a certain standard on Newfoundland and Labrador public utilities. However, these are insufficient considering the prevailing NERC standards, as they do not provide citizens or the Board with sufficient legislative authority to demand reliable service.

\section{4.a Devising a definition of "adequate planning"}

In looking to how various courts have interpreted "adequate planning," the interpretations of "adequate" and "planning" 
support a definition of "adequate planning" as: an ongoing process, frequently reviewed, that ensures consistent, dependable access to electricity in Newfoundland and Labrador.

"Adequate" has been deemed synonymous with "reasonably reliable," "sufficient," and "good and sufficient" (Words \& Phrases, n.d., 23480). The Canadian Human Rights Tribunal, in PSAC V Canada Post Corp, found this to be the case in the context of the reliability of job information, defining "reasonably reliable" as "consistently, moderately dependable or in which moderate confidence can be put" (Words \& Phrases, n.d., 23480). In the real property context, Brocklebank v Colwill dealt with the meanings of "good" and "sufficient," with "good" referring to "the condition of the roadway being suitable for the purpose required" (Words \& Phrases, n.d., 14472) and "sufficient" was found to be "broad enough to enable the occupant of the tenement to use the [roadway] conveniently" (Words \& P hrases, n.d., 14472).

"Planning" was discussed in Toews v Mackenzie as being "the method of using scarce resources of balancing thrift and efficiency... [or achieving] a policy pursuant to a discretionary power given by a statute" (Words \& Phrases, n.d., 9966). Similarly, R v Widdifield saw it as "a calculated scheme or design which has been carefully thought out, the nature and consequences of which have been considered and weighed" (Words \& Phrases, n.d., 9966). Further, Ontario courts have viewed it as incorporating the idea of "an ongoing process...[that] should be reviewed and amended from time to time in light of changing circumstances" (Words \& Phrases, n.d., 9966).

\section{4.b Devising a definition of "reasonable service"}

As mentioned above, the Public Utilities Act defines "service" as "the use and accommodation given to consumers or patrons, and a product or commodity provided by a public utility, and [equipment used to perform a service)" (Public Utilities Act, 1990, s 2(1)(f)). Building on this, based on courts' interpretations of "reasonable," in the consumer context it is plausible to argue for a definition of "reasonable service" such as: objectively proper, fair, and appropriate provision of public utilities to customers and patrons.

"Reasonable" has been defined in the labour employment context as an "objective [test] insofar as it may be necessary to examine the position of the employee in the light of what other employees in similar positions in the same field of employment might do" (Words \& Phrases, n.d., 4172). Further, Russell Transport Ltd $v$ Ontario Malleable Iron Co found the term to mean "more than merely 'taking proper care"' (Words \& Phrases, n.d., 4172). Black's Dictionary defines "reasonable" as "fair, proper, just, moderate, suitable under the circumstances, fit and appropriate to the end in view, having the faculty of reason, rational, governed by reason, under the influence of reason, agreeable to reason" (Words \& Phrases, n.d., 4172). Extrapolating this concept to the public utilities context, it would indicate that a public utility should be examined in light of what other public utilities in similar positions may do. Given the unique nature of the Newfoundland and Labrador electrical grid, it is likely that this would not require the NERC standards that all other Canadian provinces adhere to. However, a policy that is based on the values the NERC standards espouse would likely be a metric to judge Newfoundland and Labrador public utilities by. 


\subsection{Newfoundland \& Labrador's regulatory setup impairs its ability to effectively regulate public utilities}

Newfoundland and Labrador is in the minority of $C$ anadian provinces with respect to the complexity and depth of energy regulation employed by the province and independent boards to develop and enforce standards. By way of example, in comparison to Newfoundland and Labrador's Board that manages enforcement of all energy regulations in the province, Alberta and Ontario have multiple bodies responsible for managing and regulating the energy sector.

In direct contrast to the Newfoundland and Labrador system, the Ontario and Alberta public utilities are required by law to provide reliable service in accordance with NERC standards. These standards are more stringent than Newfoundland and Labrador's use of "adequate planning" and "reasonable service" to describe the efforts required on the part of public utilities in the provision of electricity to customers. While these provinces represent potential models for public utilities management in Newfoundland and Labrador, the direct applicability may be constrained by the very nature of the Newfoundland and Labrador Island Interconnected System, as it lacks a connection to the mainland bulk power grid.

\section{5.a Ontario's public utilities regulatory system is superior to Newfoundland and Labrador's system}

In Ontario, key players in the regulation of public utilities are the Minister of Energy; Ontario Energy Board; and the Independent Electricity System Operator and its Market Assessment and Compliance Division (NERC, 2015A). The Ontario Energy Board's powers with respect to electricity are primarily governed by the Ontario Energy Board Act, 1998 and the Electricity Act (Ontario Energy Board, 2014). The board's objectives with respect to electricity include "[t]o protect the interests of consumers with respect to prices and the adequacy, reliability and quality of electricity service" (Ontario Energy Board Act, 1998, s. 1(1)). The Ontario system employs all NERC reliability standards declared in force in the United States, except for an order to stay or remand the standard by the Ontario Energy Board (NERC, 2015A).

\section{5.b Alberta's public utilities regulatory system is superior to Newfoundland and Labrador's system}

Alberta operates a competitive, rather than monopolized, energy market. Alberta employs Alberta Energy, the Alberta Utilities Commission, Alberta Electric System Operator ("AESO"), and the Market Surveillance Administration in the regulation of public utilities. Thus, there is a heightened level of accountability on the utilities, and the agencies themselves, in the operation of the public utilities market in Alberta (NERC, 2015A). The Alberta Utilities Commission, which regulates the utilities sector, natural gas and electricity markets, is primarily governed by the Alberta Utilities Commission Act, Electric Utilities Act, Hydro and Electric Energy Act, and Public Utilities Act in its role to monitor the provision of electricity (Alberta Utilities Commission, n.d.). AESO's mandate is "to direct the reliable operation of the Alberta interconnected electric system (AIES), plan the transmission system, and operate the wholesale electricity market" (NERC, 2015A). Alberta also incorporates the NERC reliability standards into its 
legislative scheme through its Transmission Regulation (Transmission Regulation, 2007, s. 19(1)(a)). Per AESO, reliability is "the combination of adequacy and system security," which are terms defined by NERC (Alberta Electric Systems Operator, 2015).

\section{Recommendations for legislative revisions and the necessary implications}

The primary concern with the current Newfoundland regulatory framework is the inability of the Board to qualify reliability as a component of customers' service that energy providers must maintain. In using language that mandates public utilities be "reasonably safe, adequate, just, and reasonable," the legislation effectively permits a significant margin of error in the operation of public utilities and the provision of service to customers (Public Utilities Act, 1990, s. 37). As this is the legislative requirement for public utilities, the question becomes a matter of what authority the Board must require that public utility service is reliant upon, unless unforeseen circumstances make that an impossibility.

While the logical conclusion may be, and likely is, to insert a "reliability" requirement into the Public Utilities Act and the Electrical Power Control Act, one must explore the consequences of such an action. All other Canadian provinces adhere to the NERC standards that clearly and explicitly define reliability. As such, the inclusion of a "reliability" requirement into Newfoundland and Labrador's legislation would likely necessitate the use of a reliability definition similar in nature to that employed by NERC. It is important to note whether or not these types of policies would be amenable to the Newfoundland populous and the legislative scheme of the province. The system in its current capacity appears unable to substantiate such reliability standards; however the opening of the Muskrat Falls facility will provide the province with an effective capacity and robust system to develop greater reliability standards.

\subsection{Muskrat Falls development benefits and concerns}

Muskrat Falls is a Nalcor Energy development that is intended to generate electricity from an 824-megawatt hydroelectric facility in response to growing energy demands in Newfoundland and Labrador. Nalcor Energy estimates that the project will have a life of more than 100 years and should provide: "long-term stable electricity rates for generations of Newfoundlanders and Labradorians; lowestcost power for homes and businesses... [and] a link to North America's electricity grid for exports" (Nalcor Energy, n.d.). Nearly $40 \%$ of the facility's operating capacity will serve the Island's power needs, with the remainder allocated to Nova Scotia's Emera Inc. and other Atlantic Canadian and New England markets. This paper has primarily reviewed the Newfoundland and Labrador's electrical system in its current state prior to the inception of Muskrat Falls, as many of its effects, successful or otherwise, are largely unknown. One can hypothesize that a great many issues arose because of the province's reliance on the promise of the Muskrat Falls development, which has been in development since its approval by the provincial government in 2012 (Nalcor Energy, n.d.).

Of great importance to improving the electricity landscape in Newfoundland will be the Labrador-Island Link, which will officially connect the island portion of the province to the main energy grid. Newfoundland and 
Labrador, currently the only province not on the main energy grid, will ideally be able to capitalize on shared resources and electric generation capacity in the event of unforeseen circumstances. It is also being built with Newfoundland's geography in mind and is therefore intended to be able to withstand harsh environmental conditions (Nalcor Energy, n.d.).

However, the success of Muskrat Falls is largely unknown and it is anticipated to have a negative impact on Newfoundland and Labrador. Economic, environmental, and health consequences of Muskrat Falls represent significant risks, including: increasing the province's gross debt by $50 \%$ : further contamination of Lake Melville: and increased potential for mercury contamination in fish and seal (Patterson, 2015). Memorial University economist James Feehan argued that the root of Newfoundland and Labrador's electrical system is "provincial regulations that set artificially low prices for electricity and support excessive power consumption" (Feehan, 2012, p. 1). Feehan argues that changing prices to reflect the underlying costs would promote energy conservation and eliminate the need for Muskrat Falls (2012). At a minimum, it is clear the system faces issues of over-consumption that become an issue when adverse weather events place significant strains on the system and existing equipment.

\section{Conclusion}

This paper discusses the outages and rolling blackouts that plagued Newfoundland during the winters of 2013 and 2014. This paper contends that much of the issue is a result of inefficient operation of the infrastructure by Hydro. This extends to both equipment maintenance and load forecasting.
Subsequently, a great burden is placed on Newfoundland Power, which is ultimately responsible for cutting power to consumers if load capacity is exceeded. The Liberty Report draws out important considerations for the system, recognizing that there are inefficiencies present in the current scheme that necessitate the all-too-frequent use of outages to stabilize the system. The system also exhibits poor electricity standards, failing to mandate that reliability is an essential component to an effective legislative scheme.

In the absence of factors like those employed by NERC-abiding jurisdictions, there is a lack of enforcement of reliable energy standards in Newfoundland and Labrador. Ideally, the connection with Muskrat Falls will alleviate many of the capacity issues and stimulate Newfoundland's government to adopt legislation that either accords with NERC principles, or assigns reliability standards in alignment with those of NERC. However, the future success of the Muskrat Falls project remains uncertain. Failure to effectively address the systemic issues prevalent in Newfoundland's energy sector by the Board, provincial government, and public utilities, will result in recurring, rampant use of outages and rolling blackouts to control and stabilize the system.

\section{References}

Alberta Electric System Operator. (2015).

Consolidated Authoritative

Document Glossary. Retrieved from http://www.aeso.ca/downloads/Cons olidated_Authoritative_Document_GI ossary_(November_26_2015).pdf

Alberta Utilities Commission. (n.d.). Company website. Retrieved from www.auc.ab.ca 
ATCO Gas and Pipelines Ltd. v Alberta (E nergy and Utilities Board), 2006 SCC 4.

Board of Commissioners of Public Utilities. (2014). An Order of the Board NO.

P.U. 3. Retrieved from http://www.pub.nf.ca/orders/order20 14/pu/pu3-2014.pdf

Board of Commissioners of Public Utilities. (2015). Transcript of the Phase I Hearing. Retrieved from http://www.pub.nf.ca/applications/ls| andInterconnectedS ystem/files/trans cripts/Mar-30-2015.pdf

Board of Commissioners of Public Utilities. (n.d.). Website. Retrieved from http://www.pub.nf.ca/index.htm

The Canadian Press. (2014, J anuary 6). "Newfoundland Premier defends energy system on fourth day of blackouts." Globe \& Mail. R etrieved from

http://www.theglobeandmail.com/ne ws/national/newfoundland-closesschools-as-power-outage-entersfourth-day/article 16203471/

Electrical Power Control Act, SNL 1994, C E-5.1.

Feehan, J. P. (2012, December). "Newfoundland's Electricity Options: Making the Right Choice Requires an Efficient Pricing Regime." C.D. Howe Institute. Retrieved from https://www.cdhowe.org/newfoundla nd's-electricity-options-making-rightchoice-requires-efficient-pricingregime

Gushue, J. (2014, December 29). "\#darknl tops list of top Newfoundland \&
Labrador stories of 2014." CBC News. Retrieved from http://www.cbc.ca/news/canada/new foundland-labrador/darknl-tops-listof-top-newfoundland-labradorstories-of-2014-1.2881903

Halsbury's Laws of Canada, "Public Utilities", (Markham, Ont: Lexis Nexis Canada, 2014).

Interpretation Act, RSNL 1990, c I-19.

The Liberty Consulting Group. (2014A, A pril 24). Supply Issues and Power Outages Review Island Interconnected System: Interim Report. Retrieved from http://www.pub. nf.ca/applications/Islandlnterconnect edSystem/files/reports/Libertylnterim ReportA pril24-2014.pdf

The Liberty Consulting Group. (2014B, December 17). Report on Island Interconnected System to Interconnection with Muskrat Falls addressing Newfoundland and Labrador Hydro. Retrieved from http://www.pub.nf.ca/applications/|s| andInterconnectedS ystem/files/repor ts/The-Liberty-C onsulting-G roupHydro-R eport-12-17-2014.pdf

Nalcor Energy. (2013). 2013 Business and Financial Report. Retrieved from http://www.nalcorenergy.com/upload s/file/Nalcor\%202013\%20Annual\%2 OReport(1).pdf

Nalcor Energy. (2014). 2014 Business and Financial Report. Retrieved from http://www.nalcorenergy.com/pdf/ 2014AnnualR eport.pdf 
Nalcor Energy. (n.d.). Muskrat Falls. Retrieved from http://muskratfalls.nalcorenergy.com

Newfoundland Labrador Hydro. (n.d.). Company Website. Retrieved from https://www.nlhydro.com

Newfoundland Power. (2015A). Company Website. Retrieved from https://secure.newfoundlandpower.c om/ default.aspx

Newfoundland Power. (2015B). Third Quarter 2015. Retrieved http://www.newfoundlandpower.com/ Public ontent/8547/3rd_quarter_20 15.pdf>

North American Electric Reliability Corporation. (2007). Definition of "Adequate Level of Reliability." Retrieved from http://www. nerc.com/docs/pc/Definition-of-ALR approved-at-Dec-07-OC-PCmtgs.pdf

North American Electric Reliability Corporation. (2014B, February). Improving Coordinated Operations Across The Electric R eliability Organization (ERO) Enterprise. Retrieved from http://www.nerc.com/AboutNERC/ke yplayers/Documents/ERO_Enterpris e_Operating_Model_Feb2014.pdf

North American Electric Reliability Corporation. (2014B, November). 2014 Long-Term Reliability Assessment. Retrieved from http://www. nerc.com/pa/RAPA/ra/R eliability $\% 20$ Assessments\%20DL/2014LTRA_ER ATTA.pdf
North American Electric Reliability Corporation. (2015A, February 11). Canadian Provincial Summaries of Standard-Making and Enforcement Functions with U.S. Comparators. Retrieved from http://www.nerc.com/AboutNERC/ke yplayers/Documents/C anadian\%20P rovincial $\% 20$ Summaries $\% 20$ of $\% 20 \mathrm{~S}$ tandardMaking\%20and\%20E nforce ment $\% 20$ F unctions $\% 20$ with $\% 20$ US $\% 20$ Comparators $\% 20$ (2).pdf

North American Electric Reliability Corporation. (2015B). Corporate Website. Retrieved from http://www.nerc.com/Pages/default.a spx

Ontario Energy Board. (2014). Company website. Retrieved from www.ontarioenergyboard.ca

Ontario Energy Board Act, SO 1998, c 15, Sch B.

Patterson, B. (2015, December 18). "The economic, environmental and health consequences of the Muskrat Falls dam." The Council of Canadians. Retrieved from https://canadians.org/blog/economicenvironmental-and-healthconsequences-muskrat-falls-dam

Pennell, J. (2013, January 23). "Rolling blackouts possible: NL Hydro." The Telegram. Retrieved from http://www.thetelegram.com/News/L ocal/2013-01-23/article3162056/R olling-blackoutspossible\%3A-NL-Hydro/1

Public Utilities Act, RSNL 1990, c P-47.

Transmission Regulation, AB Reg 86/2007. 
Words \& Phrases. (n.d.). Retrieved from https://nextcanada.westlaw.com 